\title{
Selected chemical properties of sandy soil after 36 years of differential fertilization with mineral nitrogen and manure without liming in two crop rotation
}

\author{
Dorota Pikuła ${ }^{1 *}$, Agnieszka Rutkowska ${ }^{1}$ \\ ${ }^{1}$ Institute of Soil Science and Plant Cultivation - State Research Institute, Department of Plant Nutrition and Fertilization, Czartoryskich Str. 8, \\ 24-100 Puławy, Poland \\ * dr hab. D. Pikuła, dpikula@iung.pulawy.pl, ORCID iD https://orcid.org/0000-0003-4173-197X
}

Received: 10.07.2020

Accepted: 21.10.2020

Associated editor: B. Rutkowska

\section{Keywords}

Soil fertility

Plant species

Mineral fertilization

Farmyard manure

Available phosphorus

Available potassium

\begin{abstract}
The paper presents the results of the impact of long-term different crop rotation, and manure and mineral nitrogen fertilization on soil organic carbon, total nitrogen, the content of available forms of phosphorus and potassium, as well pH. This study was based on a three-factor experiment, carried out since 1979 on a loamy sand (Albic Luvisol), in which arable crops were grown in two 4-years rotations: RotA (grain maize, winter wheat, spring barley and silage maize) and RotB (grain maize, winter wheat plus mustard, spring barley and grass-clover ley). After 36 years, the soil in RotB with an increased input of organic matter (mustard and grass-clover ley) accumulated significantly larger amounts ofsoil organic carbon. However, in the absence of liming, the soil in RotB, contrary to that in RotA, became more acidic and had less amounts of available form phosphorus and potassium. The beneficial effect use of manure every 4 years in doses $40 \mathrm{t} \cdot \mathrm{ha}^{-1}$, without liming was a in a both crop rotation, especially in RotB. The results from this long-term fertilization experiment indicate that application of manure fertilizer alone is not sufficient to maintain levels of soil organic carbon and nutrients under conditions of conventional management without aboveground crop residues, such as straw or mustard that would be returned to the soil. Regular application of FYM combined with legumes increases soil organic carbon and soil nitrogen content, but does not prevent a pH decease. However, in this rotation its does not prevent a decrease in soil available forms potassium and phosphorus content either. Fertilizing the soil with mineral nitrogen prevents a steady decrease in the soil organic carbon.
\end{abstract}

\section{Introduction}

Production capacity of soils in Poland is limited due to the predominance of sandy soils (35\%) and very sand soils (30\%), thus, soils poor in humus, characterised by $\mathrm{pH}$ values a very acidic and acidic, which adversely affects their fertility (Ochal and Kopiński, 2017). In Poland, due to the simplification in crop production with prevalence of cereal monocultures as well as crop residue removal and reduced manure production intensify the process of natural soil organic degradation. In the case of sandy soils, fertility and yield can be maintained, restored, and even increased through the use of natural, organic and mineral fertilizers (Mercik et al., 2000; Maćkowiak, 2000). The most important role in maintaining soil fertility and ensuring long-term stability of crop yield is, undoubtedly, played by organic matter (Gonet, 1993). To a large extent, it determines the biological, chemical and physical properties of soils. The organic matter is the main source of nitrogen in soil. It also protects the soil against the loss of this nutrient, activing it only as a result of microbial transformations (Sulewska et al., 2017). In addition to increasing the organic matter content of the soil, it plays role in reducing the loss of nutrients from the soil, thus helping to maintain the fertility of sandy soils. Nitrogen $(\mathrm{N})$, potassium $(\mathrm{K})$ and phosphorus (P) are the major nutrients in crop fertilization. The content of available phosphorus and potassium forms in the soil is also one of the most important elements of soil fertility. Both elements determine the potential production in the soil. Phosphorus also has a very important function of the natural environment. The content of this element affects the increase of soil microbiological activity, and as a consequence, on the transformation of other nutrients in soil (Koper and Lemanowicz, 2008). Properly constructed crop rotation and the use of natural or mineral fertilizers should activate mechanisms that maintain high soils fertility. This is important for sandy soils. However, according to current rules in EU and „good agriculture practices” farmers should not use nitrogen fertilizers (mineral and 
organic) at rates higher than $170 \mathrm{~kg} \mathrm{~N} / \mathrm{ha}$, this rate corresponding to 30-40 thha $\mathrm{a}^{-1}$ of FYM (Directive 91/676/EEC (1991). All ,good crop and soil management practices" mean that all farmers and agricultural land users in Europe and elsewhere, have to comply with certain rules in order to sustain soil quality and avoid deteriorating the environment. That means that they cannot use excessive amounts of mineral fertilizes, and instead, are advised to use, e.g. more diversified crop rotations or more pro-environmental crop mamagment techniques, etc.

The aim of the study was the comparison of selected chemical soil properties: soil organic carbon content (SOC), $\mathrm{pH}, \mathrm{N}$ total, and available forms of $\mathrm{P}$ and $\mathrm{K}$ after 36 years of growing arable crops in two 4-years rotations (RotA and RotB) differing primarily with respect to organic matter management systems.

\section{Materials and methods}

\subsection{Study area}

The study was based on a three-factor long-term field experiment, which was established in 1979 at the Grabow Experimental Station (Lat: $51^{\circ} 21^{\prime} \mathrm{N}$; Long: $21^{\circ} 40^{\prime} \mathrm{E}$ ), belonging to the Institute of Soil Science and Plant Cultivation in Pulawy, Poland. The soil was classified as an Albic Luvisol (IUSS Working Group WRB, 2015 ) and is of sandy loamy texture (70\% sand, 25\% silt, $5 \%$ clay). The climate at the site is temperate with a mean annual rainfall of about $560 \mathrm{~mm}$ and a mean annual temperature of $7.8^{\circ} \mathrm{C}$. The experiment includes two 4-years crop rotations (RotA and RotB) with the following order of crops: grain maize, winter wheat, spring barley and silage maize-for RotA and grain maize, winter wheat and mustard as aftercrop for ploughing (GM), spring barley (with undersown grass-clover) and grassclover ley (GCL)-for RotB. Till 2007 potatoes were grown in both rotations, which were then replaced by grain maize in view of the rapid expansion of grain maize in Poland. Barley straw and wheat straw are harvested in both rotations. Within each rotation field, application rates of FYM and inorganic N fertilizer were varied in a split-plot design replicated in four blocks per field. Five FYM rates were assigned to main plots, starting in autumn 1979. FYM was applied in both rotations once per 4-year cycle, in the autumn preceding potatoes (grain maize), at rates of 0, 20, 40, 60 and $80 \mathrm{t} \cdot \mathrm{ha}^{-1}$. From the third rotation (in 1988)-another factor was introduced in the experiment, and that is a differentiated level of fertilization with mineral nitrogen (N0, N1, N2, N3), adjusted to the nutritional requirements of cultivated plants. Four N rates were assigned to plots within each main plot, that is per FYM rate. Doses N2 and N3 are multiples of dose N1, which, in A rotation is respectively: $50 \mathrm{~kg}$ for grain maize, $50 \mathrm{~kg}$ for winter wheat, $30 \mathrm{~kg}$ for spring barley and in the crop rotation B: $50 \mathrm{~kg}$ for grain maize, $50 \mathrm{~kg}$ for winter wheat, $30 \mathrm{~kg}$ for spring barley with catch crop, and $50 \mathrm{~kg}$ for each swath of clover-grass mixture. The doses of phosphorus fertilizers for all plants are the same in both crop rotation and amount to $24 \mathrm{~kg} \mathrm{P} \cdot \mathrm{ha}^{-1}$. Potassium fertilisers comes in appropriate doses: $71 \mathrm{~kg} \mathrm{~K} \cdot \mathrm{ha}^{-1}$ for spring barley, $83 \mathrm{~kg} \mathrm{~K} \cdot \mathrm{ha}^{-1}$ for winter wheat, $96 \mathrm{~kg} \mathrm{~K} \cdot \mathrm{ha}^{-1}$ for clover-grass mixture, $100 \mathrm{~kg} \mathrm{~K} \cdot \mathrm{ha}^{-1}$; for silo maize and $133 \mathrm{~kg} \mathrm{~K} \cdot \mathrm{ha}^{-1}$ for grain maize. $\mathrm{N}$ was applied as ammonium nitrate $(34 \% \mathrm{~N})$, $\mathrm{P}$ as triple superphosphate $\left(45 \% \mathrm{P}_{2} \mathrm{O}_{5}\right)$ and $\mathrm{K}$ as potassium chloride $\left(60 \% \mathrm{~K}_{2} \mathrm{O}\right)$. In this experiment conventional soil tillage system is used, with skimming in order to cover stubble, followed by mouldboard ploughing to $25 \mathrm{~cm}$. In this experiment no soil liming has been done to show a ,liming effect” of different rates of manure. This long-term field experiment is still ongoing.

\subsection{Analytical methods}

Soil samples were collected at the end of the growing season before ploughing (September-October) from 0-25 cm soil layer. Selected properties of the soil: the content of Corg by the Tyurin method, $\mathrm{pH}-$ potentiometrically in $1 \mathrm{~mol} \cdot \mathrm{dm}^{-3}$ $\mathrm{KCl}$ solution, content of total nitrogen (by means of the Kjeldahl method), and available forms of $\mathrm{P}$ and $\mathrm{K}$ (Egner-Riehm DL) were determined in each RotA and RotB. Due to the applicable law, currently recommended manure doses in accordance with the Directive 91/676/EEC (1991) may not exceed $170 \mathrm{~kg}$ N ha per year, which in practice means that manure cannot be used at doses higher than $40 \mathrm{t} \cdot \mathrm{ha}^{-1}$. For this reason, no results of sandy soil properties fertilized with high doses of manure (60 and $80 \mathrm{t} \cdot \mathrm{ha}^{-1}$ ) were presented. This paper presents the results of the analysis of the properties of sandy soil fertilized with the rates 0,100 and $150 \mathrm{~kg} \cdot \mathrm{ha}^{-1}$ of mineral nitrogen and $0,20,40 \mathrm{t} \cdot \mathrm{ha}^{-1}$ of manure. The data, pooled over the 36 years, were processed by the analysis of variance (ANOVA). The significant of differences was assessed by means of the Tukey method at a significance level $\alpha=0,05$. Statistical processing of the results was performed using the Statgraphic 5 Plus package (Statgraphics Plus, Rockville, USA).

\section{Results and discussion}

Before setting up the experimental field, the soil had the following properties: $\mathrm{pH}$ in $\mathrm{KCl}-5.7$, available phosphorus -57, available potassium $-121\left(\mathrm{mg} \cdot \mathrm{kg}^{-1}\right)$, total nitrogen $-6.4 \mathrm{~g} \cdot \mathrm{kg}^{-1}$, and soil organic carbon $-7.3 \mathrm{~g} \cdot \mathrm{kg}^{-1}$ of the soil soil. According to Martyniuk at al., (2019) the unquestionable benefits of regular use of manure is improving of the physico-chemical an microbiological soil properties. The positive influence of organic fertilizers on soil fertility, as well as on crop yields and their quality, has been demonstrated in the works of many researchers (Bieńkowski and Janowiak, 2006; Hofmann, 2001; Mercik et al., 2005, Pikuła et al., 2016; Stefanesccu, 2002). Under properly constructed crop rotation and the use of organic fertilizers, without using mineral fertilizers, natural mechanisms that maintain high soil fertility should be stimulated (Kęsik, 2008, Trawczyński et al., 2015). The literature on the subject indicates, however, that exclusive mineral fertilization can stabilize the organic carbon content in the soil, prevent its decrease or even increase its content (Gonet, 1993). However, in the majority of conducted experiments, an increase was recorded in the total organic carbon content on soils fertilized with manure, and manure combined with NPK (Maćkowiak, 2000; Wiśniewski and Gonet, 1986). For the research presented, the effect of crop rotation had a larger impact 
on organic carbon accumulation in soil that the effect of manure applications. The results of Table 1 indicated, that the effect of manure on soil organic carbon content was strongly linked to the crop rotation. In both crop rotations, thirty-six years of FYM application of the rates of 20 and $40 \mathrm{t} \cdot \mathrm{ha}^{-1}$ increased the soil organic carbon content. Yet, in crop rotation without legumes (RotA), the soil organic carbon content decreased to $6.25 \mathrm{~g} \cdot \mathrm{kg}^{-1}$ (average for rates of 20 and $40 \mathrm{t} \cdot \mathrm{ha}^{-1}$ ) from the initial $7.3 \mathrm{~g} \cdot \mathrm{kg}^{-1}$ content in the soil. Carbon from manure is more prone to undergo mineralization process (Antil et al,. 2011; Mercik et al., 2005). In the contrary, in crop rotation with grass-clover ley clover -RotB, the tendency of stabilization of soil organic carbon quantity in the soil was observed $-7.55 \mathrm{~g} \cdot \mathrm{kg}^{-1}$ (average for rates of 20 and $40 \mathrm{t} \cdot \mathrm{ha}^{-1}$ ) compared to the initial content of organic carbon. It was found that the crop rotation enriching soil with humus (RotB), produced organic carbon more than crop rotation without clover-grass mixture, regardless of manure fertilization. Similar results were obtained in long-term field experiments at Rothamsted (Jenkinson 1990) and at Skierniewice (Mercik et al. 1995). Those results could be explained by the fact that clover mixed with grass produce bigger amount of humus in the soil compared with manure application. On the agricultural lands, soil humus properties are mostly determined by post-harvest residue left behind after crops harvest. Legumes increase organic matter content in the soil.
The use of long-term exclusively mineral fertilization in RotA and RotB, maintained stable the content of organic carbon in the soil (Table 1). However in RotB under the influence 100 and $150 \mathrm{~kg} \cdot \mathrm{ha}^{-1}$ of mineral nitrogen, the content of organic carbon was higher than in RotA. The analysis of yields in this experiment shows that the use of 100 and $150 \mathrm{~kg} \cdot \mathrm{ha}^{-1}$ resulted in an increase of crop yields and, as a result, an increase in crop residues and roots left in the soil. Yields obtained in crop rotation A were, however, lower in comparison with the yields in crop rotation B (Ten Berge et al., 2016). For example, at the same dose of manure $-20 \mathrm{t} \cdot \mathrm{ha}^{-1}$, the yields of potato tubers in crop rotation B without any addition of mineral nitrogen amounted to $103-107 \%$ of the yields obtained in RotA at maximum dose of mineral nitrogen $150 \mathrm{~kg} \mathrm{~N} \cdot \mathrm{ha}^{-1}$. These values were $70-91 \%$ for wheat, $73-88 \%$ for barley (RotA) and $92-104 \%$ for barley (RotB), respectively.

The results of the experiment confirm that including legumes and mustard into crop rotation might be an effective method to optimize the level of soil organic carbon. Green manuring (mustard) is most often done by ploughing down biomass of cover/catch crops in order to enrich soils in organic matter, to improve soil structure and productivity (Scottti et al., 2015; MacRae and Mehuys, 1985). However, after 36 years of growing arable plants in a cropping system with an increased input of organic matter, due to growing grass-clover mixture and us-

Table 1

The effect of organic and mineral fertilizer application on soil organic carbon, $\mathrm{pH}, \mathrm{N}$ total, available nutrients $\mathrm{P}$, $\mathrm{K}$ content in the soil layer $(0-25 \mathrm{~cm})$ depending on crop rotation

\begin{tabular}{|c|c|c|c|c|c|c|c|c|}
\hline \multirow[t]{3}{*}{ Crop rotation } & \multicolumn{4}{|c|}{ Manure rates $\mathrm{t} \cdot \mathrm{ha}^{-1}$} & \multicolumn{4}{|c|}{ Nitrogen fertilization $\mathrm{kg} \cdot \mathrm{ha}^{-1}$} \\
\hline & \multicolumn{8}{|c|}{ Corg. $\left(\mathrm{g} \cdot \mathrm{kg}^{-1}\right)$} \\
\hline & 0 & 20 & 40 & Mean & 0 & 100 & 150 & Mean \\
\hline RotA & $5.0 \mathrm{a}$ & $5.6 \mathrm{a}$ & $6.9 \mathrm{~b}$ & $5.8 \mathrm{~A}$ & $6.0 \mathrm{a}$ & $6.1 \mathrm{a}$ & $6.1 \mathrm{a}$ & $6.1 \mathrm{~A}$ \\
\hline \multirow[t]{2}{*}{ RotB } & $6.8 \mathrm{a}$ & $7.4 \mathrm{~b}$ & $7.7 \mathrm{~b}$ & $7.3 \mathrm{~B}$ & $7.2 \mathrm{a}$ & $7.4 \mathrm{a}$ & $7.3 a$ & $7.3 \mathrm{~B}$ \\
\hline & \multicolumn{8}{|l|}{$\mathrm{pH}$} \\
\hline RotA & $5.1 \mathrm{a}$ & $5.1 \mathrm{a}$ & $5.4 \mathrm{a}$ & $5.2 \mathrm{~B}$ & $5.4 \mathrm{a}$ & $5.2 \mathrm{a}$ & $5.0 \mathrm{a}$ & $5.2 \mathrm{~B}$ \\
\hline \multirow[t]{2}{*}{ RotB } & $4.6 \mathrm{a}$ & $4.7 \mathrm{a}$ & $4.7 \mathrm{a}$ & $4.6 \mathrm{~A}$ & $4.9 \mathrm{~b}$ & $4.6 \mathrm{a}$ & $4.5 \mathrm{a}$ & $4.7 \mathrm{~A}$ \\
\hline & \multicolumn{8}{|c|}{$\mathrm{N}$ total $\left(\mathrm{g} \cdot \mathrm{kg}^{-1}\right)$} \\
\hline RotA & $0.6 a$ & $0.7 \mathrm{~b}$ & $0.7 \mathrm{~b}$ & $0.67 \mathrm{~A}$ & $0.7 \mathrm{a}$ & $0.8 \mathrm{~b}$ & $0.8 \mathrm{~b}$ & $0.77 \mathrm{~A}$ \\
\hline \multirow[t]{2}{*}{ RotB } & $0.7 \mathrm{a}$ & $0.8 \mathrm{~b}$ & $0.9 \mathrm{c}$ & $0.80 \mathrm{~B}$ & $0.8 \mathrm{a}$ & $0.9 \mathrm{~b}$ & $0.9 \mathrm{~b}$ & $0.87 \mathrm{~B}$ \\
\hline & \multicolumn{8}{|c|}{$\mathrm{P}\left(\mathrm{mg} \cdot \mathrm{kg}^{-1}\right)$} \\
\hline RotA & $57.5 a$ & $59.3 \mathrm{~b}$ & $68.4 \mathrm{c}$ & 61.7B & $68.0 \mathrm{c}$ & $60.2 b$ & $57.0 \mathrm{a}$ & $61.7 \mathrm{~B}$ \\
\hline \multirow[t]{2}{*}{ RotB } & $37.1 \mathrm{a}$ & $41.8 \mathrm{~b}$ & $48.4 \mathrm{c}$ & $42.4 \mathrm{~A}$ & $42.7 \mathrm{a}$ & $42.3 a$ & $42.3 \mathrm{a}$ & $42.4 \mathrm{~A}$ \\
\hline & \multicolumn{8}{|c|}{$\mathrm{K}\left(\mathrm{mg} \cdot \mathrm{kg}^{-1}\right)$} \\
\hline RotA & $96.3 \mathrm{~b}$ & $92.1 \mathrm{a}$ & $97.9 c$ & $95.4 \mathrm{~B}$ & $111.2 \mathrm{c}$ & $91.3 \mathrm{~b}$ & $84.7 \mathrm{a}$ & $95.7 \mathrm{~B}$ \\
\hline RotB & $68.1 \mathrm{a}$ & $68.9 \mathrm{a}$ & $73.9 \mathrm{~b}$ & $70.3 \mathrm{~A}$ & $69.70 \mathrm{~b}$ & $68.1 \mathrm{a}$ & $71.4 \mathrm{c}$ & $69.7 \mathrm{~A}$ \\
\hline
\end{tabular}

Treatments with the same letter are not significantly different $(\mathrm{P} \leq 0.05)$, and the comparison for mean values in crop rotation is marked with a capital letter 
ing mustard green manure, soil pH decreased in comparison with similar cropping system, but without legumes and green manure. In this experiment, no soil liming was performed to investigate soil buffering properties of FYM. This effect was evident in both crop rotations, although less pronounced in RotB. The soil $\mathrm{pH}$ values in RotA without FYM averaged 5.2 while in RotB with FYM averaged to 4.6 (Table 1). Using mustard as after crop plowed as green manure for many years and using mineral nitrogen fertlilizer use can cause a lower soil pH, which is confirmed by different studies (Schroder et al., 2011; MacRae and Mehuys, 1985). The mechanisms occurring in the soil after ploughing mustard biomass - leading to a change in the $\mathrm{pH}$ of the soil - have not been fully explained. It is generally assumed that the most important processes of proton $\left(\mathrm{H}^{+}\right)$and hydroxyl ions $\left(\mathrm{OH}^{-}\right)$generation are related to $\mathrm{C}$ and $\mathrm{N}$ transformations in soils (Butterly et al., 2013). Another factor leading to the acidification of the soil in this rotation may have been higher $\mathrm{CO}_{2}$ production during the microbiological decomposition of fresh organic matter.

Nitrogen content may change under the influence of fertilization. Selection of plants in crop rotation is a factor that shapes not only the content of organic carbon, but also the content of nitrogen in the soil (Łabza and Puła, 1996). The obtained results indicate that the basic factor determining the nitrogen content in the soil was the selection of plants for crop rotation. Changes in $\mathrm{N}$ total content due to fertilization were also determined by the type of crop rotation. The application of only manure increased the total nitrogen content in RotB by $19 \%$ in relation to RotA (Table 1). Higher nitrogen content in RotB was a consequence of including legumes in crop rotation. These results are confirmed by other studies (Krzywy et al., 1996, Mercik at al., 2005).

The content of available nutrients ( $\mathrm{P}, \mathrm{K}$ and $\mathrm{Mg}$ ) depends on the type of soil and its $\mathrm{pH}$ reaction, production intensity, crop rotation system, climatic conditions, organic and mineral fertilization, etc. Availability of nutrients increases under proper mineral and natural fertilization (Mercik et al., 2000, Sienkiewicz et al., 2004). The content of available forms of potassium in the soil rose to even a higher degree than that of phosphorus due to the long-term application of FYM (Sienkiewicz et al., 2009). Similarly to phosphorus, the concentration of $\mathrm{K}$ was the most increased in the soil fertilized with FYM alone. Frequent and intensive application of only natural or mineral fertilizers may contribute to acidification of soil, causing, for example, retardation of phosphorus (Mercik et al., 2000).

In crop rotation with legumes (RotB), decrease in the available forms of $\mathrm{P}, \mathrm{K}$ in soil was observed, contrary to RotA (Table 1). In RotA, the average content of available potassium was 95,5 $\left(\mathrm{mg} \cdot \mathrm{kg}^{-1}\right)$ while the content of available phosphorus was $61,7\left(\mathrm{mg} \cdot \mathrm{kg}^{-1}\right)$. In RotB, the average content of available potassium was lower by $26 \%$, while of available phosphorus $31 \%$. It was found that, the content of the available forms of these microelements depended on the dose of manure, as well as a plant selection in crop rotation. A similar relationship was obtained for available potassium. Differentiated fertilization with mineral nitrogen resulted in a decrease in the content of available forms of potassium and phosphorus in the RotA, while in the Rot, it re- mained at a similar level. Cwojdziński and Majcherczak, (1996) received a similar result. They noted a decrease in the available forms of potassium and phosphorus as a result of the long-term application of mineral fertilizers. Sienkiewicz et al., (2009) report that, manure acts also as a humus creating substance. It is a known fact that manure improves the s soil sorption complex, which retains cations by physicochemical sorption, thus preventing the leaching of elements. In the study of those authors, the effect of FYM and mineral fertilizers on the content of basic nutrients in soil (P, K and $\mathrm{Mg}$ ) was found to be extremely favourable. In the absence of FYM, over time the $\mathrm{K}$ balance become strongly negative in RotB and ranged from minus 100 to minus $420 \mathrm{~kg} \cdot \mathrm{ha}^{-1} \mathrm{~K}$ for four years ${ }^{-1}$ (Pikuła at al., 2016). The P balance was negative in RotB during the initial years, before $\mathrm{P}$ offtake declined. The contrast in $\mathrm{K}$ balance between RotA and RotB was due to larger $\mathrm{K}$ offtake in clover-grass mixture than in silage maize. It can be assumed that the increasing acidification of soil caused by mineral nitrogen stimulated the leaching of potassium (Kaniuczak, 1999).

The severity of crop management-induced (e.g. crop rotation, fertilization, soil tillage) changes in soil organic carbon depended on the starting level of soil organic carbon; equivalent treatments may lead to an increase in SOC from a low starting level, but a decrease from a high starting level (Körschens et al., 2013). This regularity also applies to changes in soil $\mathrm{pH}$, total nitrogen content and the content of available forms of potassium and phosphorus in the soil. A much lower content of available forms of potassium and phosphorus in the soil in RotB resulted from higher crop yields in this crop rotation (Ten Berge et al., 2016). For example average crop yields $\left(\mathrm{t} \cdot \mathrm{ha}^{-1}\right)$ in Rot $\mathrm{B}$ were: potatoes -7.71 , winter wheat -6.14 , spring barley 4.28 , grass-clover ley (GCL) - 12.25, and average crop yields $\left(\mathrm{t} \cdot \mathrm{ha}^{-1}\right)$ in Rot A were: potatoes -6.09 , winter wheat -5.47 , spring barley 3.90, silage maize 12.5. Higher crop yields indicate higher plant offtake and export of nutrients $\mathrm{K}$ and $\mathrm{P}$ from the soil in RotB than in RotA.

Perhaps the increased content of organic carbon in RotB caused phosphorus leaching from the soil. Phosphorus and potassium from manure moved to deeper layers more easily than from mineral fertilizers (Stępień and Mercik, 1999). Others authors report that in acidic soils, phosphorus tends to transform into non-assimilable forms, and is not lost. It can be recovered using soil liming (Szymańska et al., 2005). Furthermore, the reduction of available phosphorus and available potassium in the soil over thirty six years compared to the initial value, can be explained as the effect of tillage intensity and regular removal of straw from the field, because straw has significant fertiliser value in terms of $\mathrm{P}$ and $\mathrm{K}$.

\section{Conclusions}

The results of 36-year research indicate that crop rotation and fertilizing with manure are major factors improving and maintaining fertility of sandy loamy soil. The mineral nitrogen fertilization prevents a steady decrease in the soil organic carbon in the soil, and in combination with the proper plants in crop 
rotation, it even increases its content in the soil. The application of organic fertilizer into the soil at the rates of $40 \mathrm{t} \cdot \mathrm{ha}^{-1}$ once every 4 years, combined with cropping of legumes and mustard in crop rotation, stabilizes the content of Corg in the soil, but does not prevent a $\mathrm{pH}$ decrease. However, in such a crop rotation, it does not prevent a decrease in potassium and phosphorus in the soil. Regular soil liming is necessary even when the soil is fertilized with manure and crop rotation is used to enrich the soil with fresh organic matter.

\section{Acknowledgements}

This work was supported by the Tasks 2.2 of the State Project IUNG-PIB founded by Polish Ministry of Agriculture and Rural Development.

\section{References}

Antil, R.S., Bar-Tal, A., Fine P., Hada A., 2011. Predicting nitrogen and carbon mineralization of composted manure and sewage sludge in soil. Compost Science and Utilization 19,3. https://doi.org/10.1080/ 1065657X.2011.10736974

Bieńkowski, J., Janowiak, J., 2006. The state of humus in the soil in longterm static fertilization experiments. Fragmenta Agronomica 2, 16-225. (in Polish with English abstract)

Butterly, C.R., Baldock, J.A. \& Tang, C., 2013. The contribution of crop residues to changes in soil pH under field conditions. Plant and Soil 366, 185-198. https://doi.org/10.1007/s11104-012-1422

Cwojdziński, W., Majcherczak, E., 1996. The Effect of 20-Year Mineral and Organic Fertilization on Yield of Plants and Some Properties of Soil. Zeszyty Naukowe Akademii Rolniczej Szczecin - Scientific Journals of the Agricultural University of Szczecin 172, Rolnictwo - Agriculture 62, 77-84. (in Polish with English abstract)

Directive 91/676/EEC of the European Parliament and of the Council of 12 December 1991 concerning the protection of waters against pollution caused by nitrates from agricultural sources, (Dz.U. UE L 31 December 1991).

Gonet, S.S., 1993. The state of humus in the soil in long-term static fertilization experiments. Zeszyty Naukowe Akademii Rolniczej Kraków - Scientific Journals of the Agricultural University of Krakow 277, 37, 39-49. (in Polish with English abstract)

Hofmann, J., 2001. Assessment the long-term effect of organic and mineral fertilization on soil fertility. $12^{\text {th }}$ WFC Fertilization in the third millennium. Beijing.

Jenkinson, D.S., 1990. The turnover of organic carbon and nitrogen in soil. Philosophical Transactions of the Royal Society B 329: 361-368.

Kaniuczak, J., 1999. Content of some magnesium forms in grey-brownpodsolic soil depending on liming and mineral fertilization. Zeszyty Problemowe Postępów Nauk Rolniczych - Advances of Agricultural Sciences Problem Issues 467, 307-316. (in Polish with English abstract)

Kęsik, T., 2008. Cropping pattern and its influence on agricultural ecosystem. Zeszyty Problemowe Postępów Nauk Rolniczych - Advances of Agricultural Sciences Problem Issues 527, 39-50. (in Polish with English abstract).

Koper, J., Lemanowicz, J., 2008. Effect of varied mineral nitrogen fertilization on changes in the content of phosphorus in soil and in plant and the activity of soil phosphatases. Chemia i Inżynieria Ekologiczna Ecological Chemistry and Engineering 15(5), 465-47. (in Polish with English abstract)
Körschens, M., Pfefferkorn, A., 1998. Der Statische Düngungsversuch Bad Lauchstädt undandere Feldversuche [The static fertilization experiment and other long-term field experiments]. UFZ-Umweltforschungszentrum Leipzig-Halle GmbH. 56.

Körschens, M., Albert, E., Armbruster, M., Barkusky, D., et al., 2013. Effect of mineral and organic fertilization on crop yield, nitrogen uptake, carbon and nitrogen balances, as well as soil organic carbon content and dynamics: results from 20 European long-term field experiments of the twenty-first century. Journal Archives of Agronomy and Soil Science Vol. 59, 8. https://doi.org/10.1080/03650340.2012.704548

Krzywy, E., Krupa J., Wołoszyk, Cz., 1996. Impact of long-term organic and mineral fertilization on some soil fertility indicators. Zeszyty Naukowe Akademii Rolniczej Szczecin - Scientific Journals of the Agricultural University of Szczecin 172, Rolnictwo - Agriculture 62, 259-264. (in Polish with English abstract)

IUSS Working Group WRB, 2015. World Reference Base for Soil Resources 2014, update 2015. International soil classification system for naming soils and creating legends for soil maps. World Soil Resources Reports No. 106. FAO, Rome.

Łabza, T., Puła. J., 1996. Total nitrogen content in soil under conditions of crop rotation transport. Zeszyty Naukowe Akademii Rolniczej Szczecin - Scientific Journals of the Agricultural University of Szczecin 172, Rolnictwo - Agriculture 62, 303-310. (in Polish with English abstract)

MacRae, R.J, Mehuys, G.R., 1985. The effect of green manuring on the physical properties of temperate-area soil. Advances in Soil Science 3, 71-94.

Maćkowiak, Cz., 2000. The effect of plant selection in the crop rotation, manure and mineral fertilizers on the organic carbon content in the soil and the productivity of the rotations. Nawozy i Nawożenie - Fertilizers and Fertilization 4(5), II, 91-102. (in Polish with English abstract)

Martyniuk, S., Pikuła, D., Kozieł, M., 2019. Soil properties and productivity in two long-term crop rotations differing with respect to organic matter management on an Albic Luvisol. Scientific Reports. https://doi. org/10.1038/s41598-018-37087-4

Mercik, S., Stępień, W., Figat E., 1995. The carbon and nitrogen dynamic process in the soil and the fate of $\mathrm{N}$ applied to soil with mineral and organic fertilizers in the long-term static experiments. Zeszyty Problemowe Postępów Nauk Rolniczych - Advances of Agricultural Sciences Problem Issues 421a, 277-284. (in Polish with English abstract)

Mercik, S., Stępień, W., Lenart, S., 2000. Soil fertility in three fertilization languages: mineral, organic and organic-mineral-in long-term experiment. Part I.24. Physical and physicochemical properties of soils. Folia Pomeranae Universitatis Technologiae Stetinensis, 11, Agriculture 84, 311-316. (in Polish with English abstract)

Mercik, S., Stepień, M., Stępień, W., Sosulski, T., 2005. Dynamics of organic carbon content in soil depending on long-term fertilization and crop rotation. Roczniki Gleboznawcze - Soil Science Annual 54(3/4), 53-60. (in Polish with English abstract)

Ochal, P. Kopiński, J., 2017. The effect of soil acidification on the environment and plant production, Studia i Raporty IUNG-PIB - Studies and Reports of IUNG-PIB, Fertilization and the Environment 53(7), 9-25.

Pikuła, D., Berge, Ten H.F.M., Goedhart, P.W., Schröder, J.J., 2016. Apparent nitrogen fertilizer replacement value of grass-clover leys and of farmyard manure in an arable rotation. Part II: farmyard manure. Soil Use and Management, 32 S1. ISSN 0266-0032, 20-31. https://doi. org/10.1111/sum.12246

Schroder, J.L. et al., 2011. Soil acidification from long-term use of nitrogen fertilizers on winter wheat. Soil Science Society of America Journal 75, 956-961. https://doi.org/10.2136/sssaj2010.0187.

Scottti, R., Bonanomi, G., Sceleza, A., Zoina, A. \& Rao, M.A., 2015. Organic amendments as sustainable tool to recovery fertility in intensive 
agriculture systems. Journal of Soil Science and Plant Nutrition 15(2), 333-352. http://dx.doi.org/10.4067/S0718-95162015005000031

Sienkiewicz, S., Krzebietke, S., Wierzbowska, J., Czapla, J., 2004. Changes of chemical properties of soil in relation to fertilization system. Annales Universitatis Mariae Curie-Skłodowska, sectio G (Ius), E, 59/1: 415-422. (in Polish with English abstract)

Sienkiewicz, S., Krzebietke, S., Omilian, M., Wojanowska, T., Żarczyśki, P., 2009. Effect of long-term differentiated fertilization with farmyard manure and mineral fertilizers on the content of available forms of $\mathrm{P}, \mathrm{K}$ and $\mathrm{Mg}$ in soil. Journal of Elementology 14(4), 779-786. DOI: 10.5601/jelem.14.4.779-786. (in Polish with English abstract)

Stefanescu, M., 2002. Researches regarding the influence of manure in wheat - maize rotation. In: Biologie si Biodiversitate, Timisoara: 243. https://doi.org/10.4172/2329- 8863.1000269.

Stępień, W., Mercik, S., 1999. Changes of the phosphorus and potassium contents in soil and crop yielding along 30-years, on the soil fertilized and not fertilized with these nutrients. Zeszyty Problemowe Postępów Nauk Rolniczych - Advances of Agricultural Sciences Problem Issues 467, 269-278. (in Polish with English abstract).

Sulewska, A., Ratajczak, K., Niewiadomska, A., 2017. Changes in selected chemical properties of soil under maize grown in monoculture for silage as a result of application of aftercrop, straw or natural fertilizers. Journal of Research and Applications in Agricultural Engineering 62(4), 156-161. (in Polish with English abstract)

Szymańska, M., Łabętowicz, J., Korc, M., 2005. Assessment of fertilizing factors in shaping the form of phosphorus in the soil under the conditions of permanent fertilization experiment. Part I. Available phosphorus. Fragmenta Agronomica 22(1), 310-318. (in Polish with English abstract).

Ten Berge, H.F.M., Pikuła, D., Goedhart, P.W., Schröder J.J., 2016. Apparent nitrogen fertilizer replacement value of grass-clover leys and of farmyard manure in an arable rotation. Part I: grass-clover leys. Soil Use and Management 32 S1. ISSN 0266-0032, 9-19. https://doi. org/10.1111/sum.12246

Trawczyński, C., 2015. Balance of nitrogen, phosphorus and potassium in the second cycle of crop rotation in organic production system on the sandy soil. Fragmenta Agronomica 32 (2), 87-96. (in Polish with English abstract)

Wiśniewski, W., Gonet, S.S., 1986. The effect of fertilization with mineral nitrogen and manure on the fractional composition of organic soil matter, The state of humus in the soil in long-term static fertilization experiments. Pamiętnik Puławski - Puławski's Diary 87, 19-29.

\author{
Słowa kluczowe \\ Żyzność gleby \\ Gatunki roślin \\ Nawożenie mineralne \\ Obornik \\ Przyswajalny fosfor \\ Przyswajalny potas
}

\section{Wybrane właściwości chemiczne gleby piaszczystej po 36 latach zróżnicowanego nawożenia azotem mineralnym i obornikiem bez wapnowania w dwóch płodozmianach}

\section{Streszczenie}

W artykule przedstawiono wyniki wpływu wieloletniego zróżnicowanego płodozmianu, nawożenia obornikiem i azotem mineralnym na zawartość węgla organicznego w glebie, azotu całkowitego, przyswajalnego fosforu i potasu oraz $\mathrm{pH}$. Wieloletnie doświadczanie polowe prowadzone jest nieprzerwalnie od 1979 r. Trzyczynnikowe doświadczenie jest zlokalizowane na glebie Albic Luvisol (WRB, 2015) o uziarnieniu piasku gliniastego lekkiego, w którym rośliny uprawiane są w dwóch 4-letnich zmianowaniach: RotA (kukurydza na ziarno, pszenica ozima, jęczmień jary i kukurydza na kiszonkę) oraz RotB (kukurydza na ziarno, pszenica ozima, gorczyca na poplon, jęczmień jary i mieszanka koniczyny z trawami). Po 36 latach gleba w RotB ze zwiększonym dopływem do gleby materii organicznej (gorczyca na przyoranie i mieszanka koniczyny z trawami) akumulowała znacznie większe ilości węgla organicznego. Jednak przy braku wapnowania gleba w RotB, w przeciwieństwie do tej w RotA, uległa większemu zakwaszeniu, charakteryzowała się zmniejszoną zawartością przyswajalnego fosforu i potasu. Wyniki tego wieloletniego eksperymentu nawozowego wskazują, że stosowanie tylko nawożenia obornikiem nie jest wystarczające do zwiększenia/utrzymania zawartości węgla organicznego w glebie na optymalnym poziomie w warunkach konwencjonalnej uprawy roślin, bez przyorywania słomy i poplonów. Zastosowanie dopiero nawożenia obornikiem $\mathrm{w}$ połączeniu z właściwie skonstruowanym zmianowaniem z udziałem rośliny bobowatej i nawożeniem azotem mineralnym zwiększa zawartość węgla organicznego w glebie i azotu w glebie, ale nie zwiększa zawartości przyzwalanych form fosforu i potasu, nie niweluje też zakwaszenia gleby. Nawożenie azotem mineralnym zapobiega systematycznemu obniżaniu się poziomu węgla organicznego w glebie. 